\title{
Evolution of Waste Water Treatment Technology and Impact of Microbial Technology in Pollution Minimization during Natural Fiber Processing
}

\author{
Amrita Chakraborty ${ }^{1}$, Ankurita Bhowmik ${ }^{1}$, Sangita Jana ${ }^{1}$, Pranami Bharadwaj ${ }^{1}$, Dimpal Das ${ }^{1}$, Bhaskar Das ${ }^{1}$, \\ Pintu Debnath ${ }^{2}$, Basant Kumar Agarwala ${ }^{3}$ and Shaon Ray Chaudhuri ${ }^{1 *}$
}

${ }^{1}$ Department of Microbiology, Tripura University, Suryamaninagar, India

${ }^{2}$ Department of Physics, Tripura University, Suryamaninagar, India

${ }^{3}$ Department of Zoology, Tripura University, Suryamaninagar, India

Submission: April 18, 2018; Published: May 02, 2018

*Corresponding author: Shaon Ray Chaudhuri, Department of Microbiology, Tripura University, Suryamaninagar, Tripura West, India, Tel: +919831034236; Email: shaonraychaudhuri@tripurauniv.in

Keywords: Water treatment technology; Microbial technology; Natural fiber; Textile raw material; Lustrous fiber; Antibacterial function; Pectin, Lignin; Hemicellulose

Abbreviations: COD: Chemical Oxygen Demand; BOD: Biological Oxygen Demand; TSS: Total Suspended Solids; GOI: Government of India

\section{Introduction}

Textile is critical to the development of human civilization as well as a part and parcel of daily life. Ramie, one of the most popular textile raw material with distinctive characteristics, produces the strongest and longest natural fiber with lustrous silky appearance. The appearance of the final treated fiber has a lot to do with the processing method used [1]. This type of fiber possesses many excellent properties such as high tensile strength, high moisture absorption, good thermal conductivity, outstanding antibacterial function and favourable air permeability [2]. However, raw Ramie is extracted as fiber bundles consisting of many individual fibers adhering to each other. The gum contents, such as pectin, lignin and Hemicellulose, are required to be degummed by placing in hot water or chemical solutions to free and extract the individual cellulose fibers, so as to further improve their downstream processing ability. The processing of the fiber requires large volumes of water; strong chemicals along with energy. The effluent in turn needs to be processed before discharging into the environment.

The textile sector has a high water demand be it for growing the fiber or processing it with accompanying release of toxic chemicals that are used during the process. Its biggest impact on the environment is related to primary water consumption $\left(80-100 \mathrm{~m}^{3} /\right.$ ton of finished textile) and waste water discharge (115-175kg of COD/ton of finished textile), a large range of organic chemicals, low biodegradability, colour, salinity [3]. The problem becomes even more severe since 40-65L of effluent is generated per kilogram of cloth produced. Of this amount, process water accounts for $90-94 \%$ while cooling water accounts for $6-10 \%$. The composition of the effluent also varies with the upstream processing. It is estimated that about $15-30 \%$ of the dyes utilized for colouring the final products in textile industry remain in the effluents [4]. Textile industry producing natural fibers is the second highest pollutant of clean water. These effluents have high Chemical Oxygen Demand (COD), Biological Oxygen Demand (BOD), Total Suspended Solids (TSS). The waste water thrown out from industries is either used for irrigation or allowed to run into natural sources of water [5]. These potential contaminants like the dye or colour causing compounds can pose a problem for the primary treatment facilities, including biological reactors for wastewater treatment [6]. They are subjected to primary pre treatment to remove or reduce non-biodegradable, toxic compounds as well as colour prior to a biological process. The effluent can be treated chemically, biologically or using a combination of both. The combination is advantageous due to less sludge generation and low operational cost with elevated COD removal. Since the textile sector is growing and so is the scarcity of fresh water, it poses a serious environmental concern forcing the organizations and the researchers to think about alternative fiber processing techniques with less pollution and water consumption.

Textile wastewater treatment and reuse is a promising means of conserving and augmenting available water resources 
and reducing harmful pollutant discharge into the environment. As textile companies move toward pursuing sustainability goals to reduce operational costs and complying with increasingly rigid regulations of the Environmental Protection Agencies, it is becoming apparent that water reuse is one of the key components of these initiatives which has duel function of reducing cost of purchasing fresh water and reducing paying of surcharges for discharging improperly treated wastewater. Treated water reuse will continue to be important goals for environmental pollution prevention/reduction practices in the industry (textile, fertilizer production, dairy effluent treatment to name a few). The textile industry will continue to choose and utilize water treatment solutions not only to reduce its operating costs, but also to reduce its water footprint and decrease the ecological impact from its wastewater discharge and solids sludge generation on the surrounding ecosystem. The reuse becomes further important due to water scarcity issues. With an increasingly growing and progressively affluent global population, demands on the world's global water resources will necessitate higher water costs and stricter regulations. This is propelling textile companies and municipalities alike to re-evaluate their practices and push toward a more sustainable future. Optimizing more efficient methods to minimize pollution generation, coupled with advanced treatment solutions to treat and reuse wastewater and process water, will remain an important consideration for textile manufacturing companies across the world in the future. The impact of the textile industry on the earth's body of water can be tremendous and there are ways to minimize its repercussions to the environment. While each method of effluent treatment has certain disadvantages, it's comforting to know that research is continually going on to find the most effective treatment to lessen the impact of textile effluents on the ecosystem.

There is an extensive history of water management, which in a way can be called the history of humankind as since the inception, access to the water resources has been an essential element for our survival. Arguments may be put forward stating that history of water management is irrelevant as the conditions in past and present situations are different. But such arguments would overlook the important trans-cultural structures and principles that reflect evolution of human civilization. Water management technology dates back to 2000BC as evident from ancient Greek and Sanskrit writings. People were aware of sand and gravel filtration, boiling, and straining of potable water. However they were not aware about chemical contamination or the presence of microorganisms. When people lived a nomadic life, they left their solid waste behind, which decomposed in due course of time. But when they opted for permanent settlement, such disposal became problematic and caused the water bodies to be polluted by the huge amount of waste dumped in them. The Industrial Revolution (1760-1890) quickly led to heavy migration to the cities leading to terribly over-polluted roads and water bodies. One of the earliest techniques involved in effluent treatment was land application on agricultural land.
During 1840 s and 1850s, there was a disastrous spread of waterborne diseases like cholera and typhoid. Engineering solutions were implemented when the water supply links with these diseases became clear. In the late 19th century, most cities developed more expensive systems for sewage treatment. Odour was considered the big problem in waste disposal and to address it, sewage were drained to a lagoon, or settled and the solids removed, to be disposed of separately. This process is now called primary treatment and the settled solids are called sludge. During the Great Depression and the World War II (1920-1945) in early $20^{\text {th }}$ century, the health problems associated with water pollution seemed to be resolved in the industrialized countries when chlorination and other water treatment techniques were developed and widely taken into use. Microbiological problems related to water began to be largely considered a problem of the developing world. During the last part of the $20^{\text {th }}$ century industrial pollution increased manifold leading to the enforcement of Federal Water Pollution Control Act in 1948 followed by the Safe Drinking Water Act in 1972. In the present scenario, Sustainable Development Goals formulated in 2015 included targets on access to water supply and sanitation at a global level. This is something to keep in mind when assessing future options and considering required strategies [7-10].

At present, it is not only the treatment of generated waste water which is an active area of research for textile industries; but also looking for green technology for minimizing the chemical and water use by replacing it with enzymes to reduce pollution. In recent years, emphasis has been put on developing cleaner, cost-effective, and value-added textile products for a variety of applications without compromising the issues related to environmental health [11]. As part of this attempt of the textile industry to focus on the use of green technologies as alternative to conventional wet processes to promote sustainable production and consumption of textiles, microbial enzymes are finding their place in the market. They are being used for degumming of natural fibers (bacteria), bio bleaching, microbial treatment of recalcitrant organo-pollutants (white rot fungi) $[12,13]$. The result is less use of chemicals and hence less discharge of unused chemicals; less energy consumption as most enzymes do not need very high temperature and better finished products with smooth, lustrous fiber which could get into fabric (Figure 1) and proper degradation of the pollutants in the effluent. Most of the natural fiber require retting, which constitutes a vital step in the production of fibers like hemp, jute and flax is essentially a microbial decomposition process and depends upon the property of microorganisms to produce pectic enzymes that decompose pectic substances binding together the fibers [14]. Hence Microbial intervention result in better finished products with less pollution. All that is required is careful selection of candidate organism for extracellular enzyme production while growing in minimal condition like the natural gum of the fiber [15]. 


\section{Current Trends in Fashion Technology \& Textile Engineering}

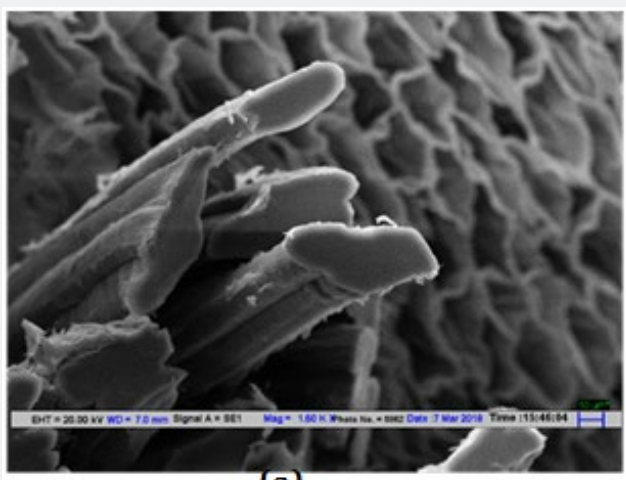

(a)

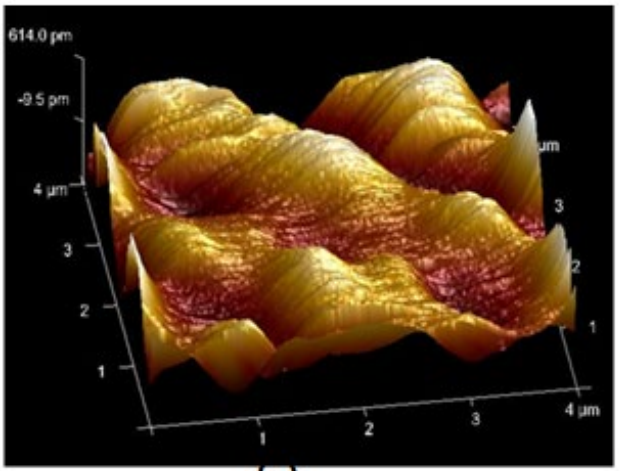

(c)

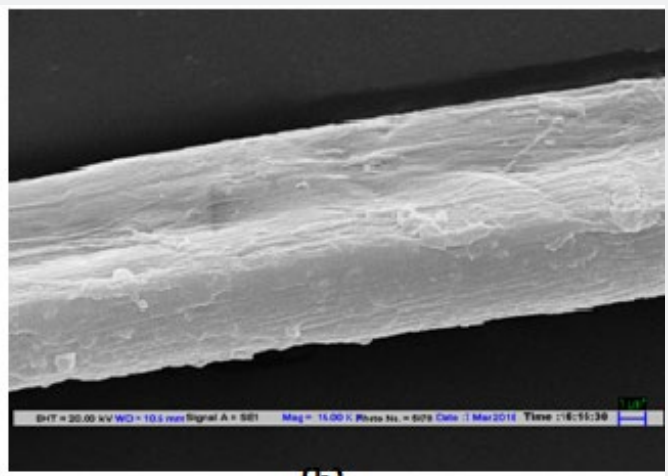

(b)

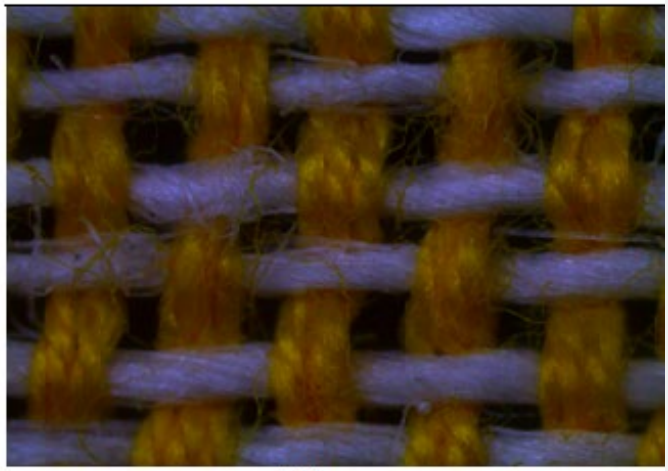

(d)

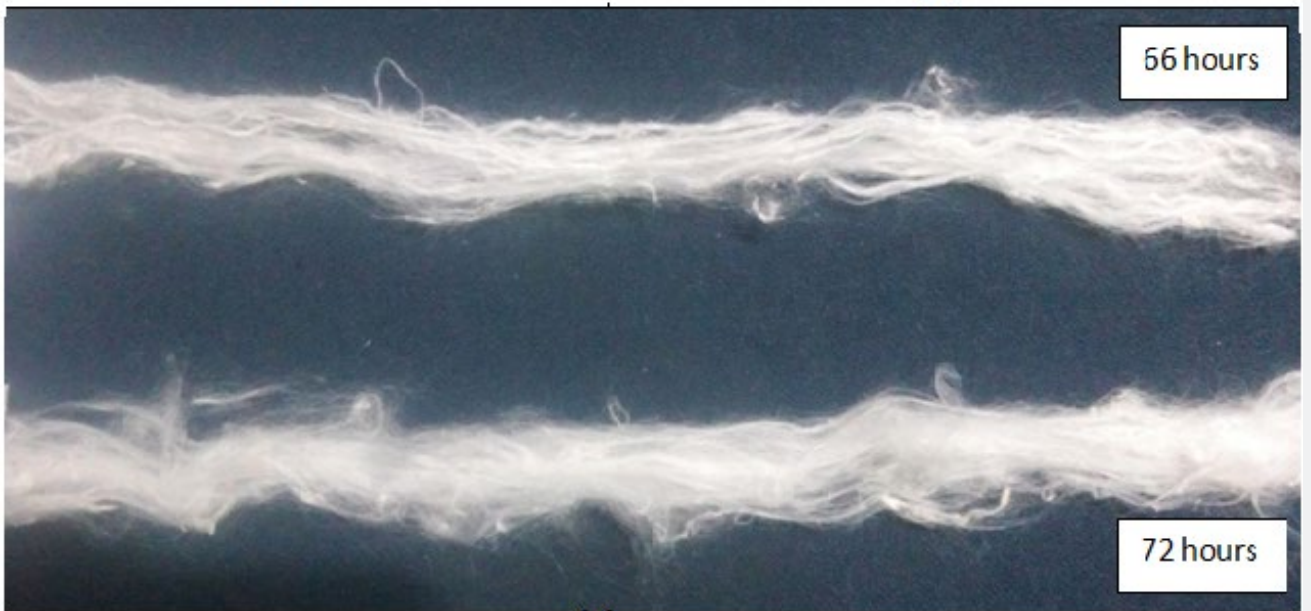

(e)

Figure 1: Ramie fiber and Fabric after microbial degumming a) Cross-section of microbially degummed Ramie fiber under scanning electron microscope; b) Longtidinal section of microbially Ramie fiber under scanning electron microscope; c) Longtidinal section of microbially Ramie fiber under Atomic force microscope; d) Ramie and Linen blended fabric under sterio microscope (Leica); e) Image representing Ramie fibers which were partially chemically treated followed by 66 and 72 hours of incubation with bacterial enzymes.

\section{Acknowledgement}

Authors acknowledge the financial assistance of Indian Institute of Social Welfare and Business Management, Kolkata, India under the Innovative Program Projects; Ministry of Human Resource Development, Government of India (GOI) under the FAST scheme for the Centre of Excellence in Environmental Technology and Management, Kolkata; Department of Biotechnology, GOI and Tripura University for the laboratory space and facilities.

\section{References}

1. Gupta M (2015) Bacillus sp MCC2138: a potential candidate for microbial degumming of Ramie. International Journal of Fiber and Textile Research 5: 39-43.

2. Li Z (2016) High-efficiency ramie fiber degumming and self-powered degumming wastewater treatment using triboelectric nanogenerator. Nano Energy 22: 548-557.

3. Savin I, Butnaru R (2008) Wastewater characterization in textile finishing mills. Environ Eng Manag J 7(6): 859-864. 


\section{Current Trends in Fashion Technology \& Textile Engineering}

4. Mishra G, Tripathy M (1993) A critical review of the treatment for decolourization of textile effluents. Colourage 40: 35- 38.

5. Vigneshpriya D (2015) Physicochemical Characterization of Textile Waste Water. International Journal of Innovative Research \& Development 4(10): 48-51.

6. Arnold R, Fletcher D, Daniels K (2016) Additional Information: Scandanavian. J Med Sci Sport 26: 348-358.

7. Richard OM (2014) Environmental Engineering Principles and Practice. Wiley Blackwell, United States.

8. Shin DH, Shim SY, Kim MJ, Oh CS, Lee MH (2014) V-shaped Pits in Regions of Ancient Baekje Kingdom Paleoparasitologically Confirmed as Likely Human-Waste Reservoirs. Korean J Parasitol 52(5): 569-573.

9. Tufekci N, Sivri N, Toroz I (2007) Pollutants of textile industry wastewater and assessment of its discharge limits by water quality standards. Turkish Journal of Fisheries and Aquatic Sciences 7(2): 97103

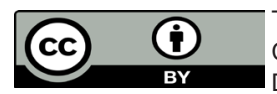

This work is licensed under Creative Commons Attribution 4.0 Licens

DOI: 10.19080/CTFTTE.2018.03.555621
10. Lofrano G, Brown J (2010) Wastewater management through the ages: a history of mankind. Sci Total Environ 408(22): 5254-5264.

11. Senthilkannan Muthu S, Kong H, Kong SAR H (2018) Textile Science and Clothing Technology Series editor. Springer, pp. 1-8.

12. Guo F, Zou M, Li X, Zhao J, Qu Y (2013) An effective degumming enzyme from bacillus sp. Y1 and synergistic action of hydrogen peroxide and protease on enzymatic degumming of ramie fibers. Biomed Res Int 2013: 212315.

13. Swamy J, Ramsay JA (1999) The evaluation of white rot fungi in the decoloration of textile dyes. Enzyme Microb Technol 24: 130-137.

14. Betrabet SM, Bhat JV (1958) Pectin decomposition by species of Pseudomonas and their role in the retting of malvaceous plants. Appl Microbiol 6(2): 89-93.

15. (1999) Pollutants of Textile Industry Wastewater and Assessment of its Discharge Limits by Water Quality Standards decoloration of textile dyes. Enzyme Microb Technol 24: 130-137.

\section{Your next submission with Juniper Publishers will reach you the below assets}

- Quality Editorial service

- Swift Peer Review

- Reprints availability

- E-prints Service

- Manuscript Podcast for convenient understanding

- Global attainment for your research

- Manuscript accessibility in different formats

( Pdf, E-pub, Full Text, Audio)

- Unceasing customer service

Track the below URL for one-step submission https://juniperpublishers.com/online-submission.php 